\title{
Local renewable energy cooperatives: revolution in disguise?
}

\author{
J. A. M. Hufen ${ }^{1 *}$ and J. F. M. Koppenjan ${ }^{2}$
}

\begin{abstract}
Background: The Eurostat statistics on the $28 \mathrm{EU}$ member states' performance in relation to renewable energy show that the Netherlands comes 25th in the EU-28. Yet, 500 initiatives were started by citizens and social groups over the last years to produce and consume renewable energy. The central question is whether these local renewable energy initiatives can be seen as a radical innovation or whether-and to what extent-they can contribute to a transition towards renewable energy production or consumption in the Netherlands.
\end{abstract}

Methods: Content analysis and case studies were the methods used in this study.

Results: The establishment of local energy cooperatives is a niche innovation in an early stage of development, and their impact on the energy production system is small, whereas local wind energy cooperatives are qualified as in a mature stage of development. Two of the four case studies of front-running local energy cooperatives demonstrate an energy transition or radical innovation in their home or facility area. One of the energy cooperatives developed an innovative concept that has potential for the production of wind energy (Deltawind). The other three energy cooperatives use a concept (sell green energy and produce renewable electricity) that is probably not suitable for large groups of clients, and the possibilities of up-scaling this formula are limited. The success of one of these three energy cooperatives (Texel Energie) is driven by the characteristics of the facility area and the social and other conditions on the island of Texel.

Conclusions: Because of the small scale of these initiatives, the performance of the Netherlands in renewable energy statistics and the rise of local energy cooperatives are not contradictory. Local wind energy cooperatives have proven to be successful, and under specific circumstances, other local energy cooperatives can be successful as well. The potential of the concept to contribute to energy transition or radical innovation is better for the local wind cooperative than for the other energy cooperatives. However, the uniqueness of each of the case studies prevents an easy reproduction of successes. The idea of up-scaling successful concepts is too simplistic, but acquiring knowledge about the mechanisms underlying energy transitions or radical innovations seems to be valuable.

Keywords: Local renewable energy; Local renewable energy cooperatives; Bottom-up innovation; Radical innovation; Energy transition; Energy innovation systems

\section{Background} Introduction

The Eurostat statistics on the 28 EU member states' performance in relation to renewable energy show that the Netherlands comes 25th in the EU-28 [1]. Around $4.5 \%$ of gross Dutch final energy consumption comes from renewable energy sources. Although ambitious policy goals regarding renewable energy were formulated, so far, the

\footnotetext{
* Correspondence: hh@qaplus.info

${ }^{1} \mathrm{QA}+$ Research and Consultancy in Leiden, Galileïweg 8, 2333BD, Leiden, The Netherlands

Full list of author information is available at the end of the article
}

Dutch government has not been able to realize its aspirations. This is surprising, because the Netherlands performs reasonable well in terms of innovation and competitiveness indexes [2].

The Eurostat statistics show a backlog in the production of renewable energy, but at the same time, many new initiatives to produce and use renewable energy have been started by citizens and social groups over the last couple of years. Recently, reports have identified 500 such initiatives in different communities [3]. There is great variety in the nature and scale of these initiatives,

\section{至 Springer}


but they share a strong commitment towards energy conservation and renewable energy. The magnitude of these initiatives came as a surprise [3]. It is interesting that these initiatives emanate from citizens and social groups, despite the fact that these groups are rarely addressed as target groups in governmental policies on renewable energy and conservation [4].

The combination of the Dutch backlog on renewable energy on the one hand, and the enthusiasm of civic and social groups in many recent local energy initiatives on the other, prompted the writing of this article. The central question is whether these local energy cooperatives can be seen as a radical innovation or whether-and to what extent-they contribute to a transition towards renewable energy production in the Netherlands.

The article first gives an overview of the Dutch energy sector. After the introduction to energy transition theory and innovation system theory, research questions are formulated, and the research method is described. The results of the research are presented. The analysis of the results is followed by the conclusions.

\section{Context}

The Dutch energy market is dominated by six private multinational energy companies (Electrabel Nederland, Eneco, E.On-Benelux, Essent/RWE, Nuon/Vattenvall, and EPZ) that produce energy mainly using fossil energy sources like gas and coal [5]. Consumer demand for green energy is covered by imports whose authenticity is claimed by a certificate. The renewable energy produced by the multinationals comes from large-scale biomass and wind energy. The share of renewable energy in the multinationals' energy production will probably not change or change only slightly, because they have invested in conventional production facilities [6]. Only one of the energy companies (Eneco) chose to prioritize investments in renewable energy [7]. Energy delivery to small-scale users is dominated by large multinational companies, whose market share of small-scale users is around $80 \%$, and this share is relatively stable [8].

In addition to the aforementioned multinational energy producers, four other energy producers operate on the Dutch energy market. These producers have chosen to distribute $100 \%$ green energy and to produce renewable energy in the Netherlands. These companies have their own strategy in the production of renewable energy, that is, the combination of solar, wind, and biomass energy (Greenchoice), biomass energy (HVC energy), and wind energy (Raedhuys, Windunie). Their investments in production facilities are small in comparison to the large energy companies [9]. Apart from the energy production enterprises (the six multinationals and the four "nationals"), 18 energy delivery companies of some magnitude distribute energy to small-scale users. Some of these energy delivery companies use the license of another energy distribution company, whereas others have their own license $[6,7]$.

Since the liberalization of the energy market in 1995, small-scale users have become active on the energy market, as indicated by the growing number of users that switch energy provider. In 2013, $12.1 \%$ of all small-scale users chose a new energy delivery company [10]. Despite the neglect of renewable energy in energy production, three million small-scale energy users (around $50 \%$ of this market segment) currently choose energy that is labeled as "green energy" for their domestic needs; however, although the number of green energy consumers is relatively stable, it has decreased a little [8]. Consumer demand can only be met by the energy producers importing green energy [11]. The origin of this so-called green energy is, however, debated by the consumer organization, Consumentenbond, as around $65 \%$ of this energy is not green $[7,12]$.

The consumer organization's criticism concerns the definition as well as the administration of green energy. The administration of green energy is criticized because the system is imperfect as it does not exclude double counting. The energy sector admits that the green energy delivered is not green in terms of the original meaning [12]. The consumer organization investigated the product characteristics of the different brands of green energy sold [6]. It proved impossible to draw clear conclusions about all the green energy labels on the market. Thus, the market for green energy is not transparent for small-scale users because false information prevents them from making a correctly informed decision about their preferred energy purchase option [7, 12].

The Dutch government has created laws and regulation of competition in the energy market and indirect incentives for consumers that have a strong impact on energy conservation and renewable energy. For example, under Dutch law, there is no obligation for energy companies to produce renewable energy. The discussion about supplier obligations to enhance energy conservation and renewable energy never resulted in a political decision to change the system [13, 14]. Furthermore, Dutch fiscal policy provides enormous tax exemptions for large-scale energy consumption. This system stimulates low prices as well as energy inefficiencies and impedes innovation such as the introduction of renewable energy [9]. At the same time, the Dutch government has been pursuing a stimulating energy policy for several decades. Although citizens were never addressed directly as a separate target group, many stimulating instruments were applied. Furthermore, the energy agreement that was signed in 2013 by government as well as private enterprises and societal groups includes the goal that one million small-scale users should be producing renewable energy for their own energy needs by 2020 [15]. The 
signatories agree to enhance the production of renewable energy by small-scale users [15].

\section{Methods}

\section{Theory and method}

Theory: energy transitions, innovation system theory

The establishment of many local energy cooperatives in a short period of time in the Netherlands raises the question of whether this trend can be interpreted as a transition in the energy production and delivery system. "Transitions" are radical societal changes in thinking, acting, and organizing that take several decades. These changes are not instantaneous but rather evolve gradually as a result of technological, social, economic, and institutional factors. The energy market is not an easy context in which to innovate production processes and products, but perhaps the energy cooperatives are a start-or even more-of an energy transition [11, 16].A successful energy transition is a bottom-up process in which local people and groups participate in new experiments and projects $[16,17]$. The energy sector is inclined to reject change, but these processes are initiated outside the system. The risk of duplicating the problems and solutions of the existing energy sector is therefore mitigated [17]. The successes in small-scale applications (niches) can under certain circumstances be up-scaled and become the new standard in the energy market (new regime) [18-20]. This type of change is the result of the drive by citizens and other societal groups. The role of government in these processes in the Netherlands is modest $[4,21]$.

The spontaneous establishment of local energy initiatives can also be conceptualized as a radical innovation. A radical innovation is a successful introduction of a new concept, product, service, or production process on a market. Innovation system theory interprets innovations as a result of the interactions between dependent consumers, producers, research and education, the political system, the supply system, and the infrastructure [22, 23]. Unlike classical innovation theory, innovation system theory does not focus only on research- and technology-related factors. Since the essence of local energy cooperatives is nontechnical innovation, an innovation system approach seems appropriate.

Innovations like local energy cooperatives can only be realized when buyers or consumers eagerly accept the new concept, service, or product. The protagonist role of consumers in an innovation system is widely recognized. The adaption curve of successful innovations reflects how more and more consumers accept the innovation. In Rogers' terminology, a small group of innovators (2.5\% of the market) is followed by a group of early adopters, then early, and late majority, and finally the laggards [24]. A radical innovation can only be realized when the innovations have specific characteristics. The most important conditions for successful innovations are 1) comparative advantages: an innovation can be successful if it offers consumers advantages in comparison to other products, concepts, and services; 2) lack of complexity: an innovation is less attractive when additional efforts to use the innovation are necessary; and 3) compatibility: an innovation that fits in the usual habits of consumers has a better chance of succeeding. The potential for innovation by local energy initiatives depends on these factors [25].

Innovation system theory points at the relevance of innovators' competitive environment. Local energy initiatives' innovations can only be successful when they can compete with the large multinational energy companies. An innovation in a local energy cooperative is the result of a bottom-up process in a horizontal network, whereas innovation in large multinationals is the result of a topdown process (pipe-line process). The development of innovations in horizontal networks can be successful in some markets even when competitors use a top-down model for innovation [26, 27].

The success of horizontal innovations has been described in many sectors but depends strongly on the characteristics of the innovation system. A necessary condition for the development of these bottom-up innovations is horizontal networks with 1) the incentive to innovate, 2) the incentive to reveal their innovation, and 3) low cost and competition advantage in relation to private enterprises [27]. If the third condition is not met, private enterprises on the market will pick up the bottom-up innovations and integrate them in their own products or services. These factors seem to be a useful conceptual framework to describe and assess the chances for success of the horizontal innovations that take place in local energy initiatives.

\section{Main question and research questions}

Main question:

Are the local energy cooperatives an energy transition or a radical innovation, or to what extent do they contribute to a change in renewable energy production and in small-scale users' energy consumption in the Netherlands?

Research questions:

1. What is the development stage of local energy cooperatives in terms of their contribution to a change in production and/or consumption of renewable energy in the Netherlands?

2. Have the frontrunners amongst the local energy cooperatives realized a radical innovation or energy transition in their facility area?

3. What are the dominant factors in the case of the frontrunners amongst local energy cooperatives 
that stimulate(d) or inhibit(ed) the (further) development of these cooperatives?

The concept of local energy cooperatives can be defined by a number of characteristics [28]:

- The initiators live in a local community (citizens and small and medium enterprises (SMEs)) and aim to develop and/or distribute renewable energy and enhance energy conservation;

- The organization seeks collaboration with other local citizens, SMEs, and local government;

- The organization starts on the basis of the enthusiasm of volunteers but develops into a legal entity like a cooperative or another legal entity.

\section{What are the development stages of an energy transition?}

The development stages of an energy transition can be described as early, mature, or late. The response of consumers is "early" when small groups of consumers use the new product, "mature" when large groups do, and "late" when only a few do not use the service [24]. Furthermore, the development can be describe in terms of the successes in small-scale applications (niches) that are up-scaled and become the new standard in the energy market (new regime) [18-20]. Development is at an early stage when niche innovations do not, or almost do not, occur, and there are no changes in a dominant regime. The development stage is mature when niche innovations have proven to be very competitive, have changed the patterns in the energy market, and have become a new standard.

\section{What is radical innovation in a local energy system?}

An energy transition or radical innovation in a facility area occurs when the consumption and/or the production of renewable energy rises strongly as a result of the local renewable energy cooperative. Renewable energy can be renewable electricity (solar panels, wind energy), heat (CHP, geothermal energy, or solar-collectors), or gas (green gas from biomaterials) [29]. Energy is "green" when it is produced by renewable sources in the Netherlands (as proven by a certificate of authenticity) or when it is produced elsewhere and is most likely produced by renewable sources $[12,30]$. A strong rise in renewable energy in a facility area as a result of a local energy cooperative occurs in the following circumstances:

1. When the use of green energy in a facility area has become much more than before, as indicated by the number of clients who buy green energy from the local energy cooperative. Comparison with the national average of green energy users (36\%) can illustrate the strength of the rise $[8,12,30]$.
2. When a lot of the energy needs of small-scale users in the facility area are covered by renewable energy production facilities produced by the local energy cooperative. The contribution of renewable energy production by a local energy cooperative can be indicated by the number of households whose energy needs are covered or by the size of the investment in relation to the size of normal investment [6].

3. When many more small-scale users (households, small, and middle-sized companies) start producing renewable energy for their own needs or re-sell it under the influence of a local energy cooperative. Statistics about the production of renewable energy by households in that facility area or in the Netherlands are indicated in the database of the production installation of energy users [31]. Another possible indicator is the percentage of average households whose energy needs are completely covered by households' renewable energy production.

The occurrence of an energy transition or radical innovation in a facility area is assessed on the basis of changes in renewable energy production and/or consumption, as illustrated in points 1-3. A strong change in renewable energy is not necessarily based on strong changes in both consumption and production of renewable energy. A change in either consumption or production can be convincing on its own.

\section{What factors determine whether to develop or up-scale a local energy cooperative?}

Innovation system theory is used in this study to identify and assess the relevance of the dominant factors that influence the development of the local energy cooperatives (see the section on theories). Firstly, the probability of an energy transition in a local energy cooperative is stronger when the following conditions occur in relation to local energy cooperatives and their clients: 1) comparative advantages, 2) lack of complexity, and 3) compatibility. Our four cases are thus analyzed in terms of these conditions. Secondly, energy transition has the potential to be successful in competition with other energy production or delivery organizations when the following crucial factors occur: 1) the incentive to innovate, 2) the incentive to reveal the innovation, and 3) low costs and competitive advantage in relation to private enterprises. Our four cases are thus analyzed in terms of these factors.

\section{Method}

The first research question was answered by content analysis of white papers, research reports, scientific or other articles, and websites. Information concerning local energy cooperatives in the Netherlands was gathered and analyzed. In addition, information was gathered 
in four interviews with frontrunners amongst the local energy cooperatives and two experts in the field.

The second and third research questions were answered by case studies of four frontrunners from their establishment and development until January 2014. White papers, (policy) reports, verbatim reports of meetings, and newspapers concerning the local cooperatives and their organizational environment were gathered and analyzed. The content analysis was facilitated by the abundance of reports by local governments and most of the local energy cooperatives. Liander [31] provided a database with statistics about the local production of different forms of renewable energy by small-scale users. Furthermore, the databases of Statistics Netherlands were used to describe the facility areas. The content analysis and the databases were used to answer the second research question, and some details were checked. The content analysis was also used to describe the background of the facility area, the services of the local energy cooperatives, and the network environment. In addition, data were collected from interviews with the local energy cooperative and the local government in the facility areas, the regional government, and the energy supplier that delivered energy before privatization and liberalization. In sum, 23 interviews were held with 17 persons connected to the case studies (some people were contacted twice). In addition, another four persons were interviewed. All the interviews were conducted using an interview protocol with relevant points, and 12 interviews were recorded in order to facilitate the analysis. Furthermore, for three of the cases, a conference about different aspects of the local cooperatives was attended. For the Goeree-Overflakkee case, the wind turbine sites were visited. The four case studies are described in terms of the relationship between local energy cooperatives and their clients, with special attention for the network in which this relationship is embedded (background, services provided, organization, and networks). In addition, research questions 2 and 3 are answered using the descriptive information about the case studies as indicated in the section on main question and research questions.

The reputation of local energy cooperatives as frontrunners was ascertained in interviews with Hier Opgewekt and an expert in this field. Hier Opgewekt acts as an independent information and communication manager in the field of Dutch local energy initiatives. The expert recently wrote a description of the Dutch local energy initiatives. Furthermore, specialist literature was used as well as information about prize-winning organizations amongst local energy cooperatives, participation on national committees of local energy cooperatives, and participation in the dissemination of knowledge about local energy cooperatives. Since several local energy cooperatives specialize in wind energy, it was appropriate to choose one such cooperative as a case study, whereas the others specialize in other renewable energy technologies. Since the number of members in a cooperative is probably part of the success of frontrunners, it is understandable that the frontrunners are larger than average, but we avoided choosing only the largest cooperatives. Most of the frontrunners are relatively old, but we also chose some cooperatives that were established not so long ago. Having taken into account the aforementioned background characteristics (technology, size, and age) of frontrunners, we selected Deltawind, Texel Energie, Grunneger Power, and Lochem Energie [21, 32].

\section{Results and discussion}

\section{Development stage of local energy cooperatives in the Netherlands}

Local energy cooperatives started to be established in the 1980s and specialized in wind energy. The first local wind energy initiatives involved researchers and technicians on university campuses. In a later stage, environmental groups and citizens started wind cooperatives that aimed to investigate the promises of new energy technologies [33-35]. To date, around 16 local wind cooperatives have been established [21, 32, 36]. Most of these wind cooperatives evolved into organizations that connected a stable number of members. The local wind energy cooperatives have contracts with energy producers in the energy markets and are bedded in as part of the energy system (regime). Local wind energy cooperatives are integrated in long-term energy production plans [37]. The wind cooperatives are an innovation with a relevant source of renewable energy that can be qualified as having left the early stage of development and having developed into a mature stage, but leaving room for further development.

Later, local energy cooperatives were established that did not specialize mostly in wind energy but stimulated all different sorts of renewable energy production and energy conservation. These cooperative experiments share a common idea, but each of them chooses its own form. We consider these local energy cooperatives as small-scale experiments or projects (niche innovations). The establishment of around 91 local energy cooperatives (not specialized in wind energy) in the last 7 years is a new reality in the Dutch energy market $[21,32,36]$. The large number of energy cooperatives means that these cooperatives cannot be seen as isolated experiments. Apart from these local energy cooperatives, the Association of Dutch Municipalities calculates that there are 400 local energy initiatives. A great variety of initiatives are included in these counts, such as technical feasibility studies, research on measures for social housing cooperatives, information evenings about insulation, and/or the installation of solar panels [3]. 
At this juncture, the establishment of local energy cooperatives (not specialized the wind energy cooperatives) is in an early stage of development [21, 38]. As $90 \%$ of the local energy cooperatives have fewer than 250 green energy consumers, the volume of their demand for green energy is modest [21]. Their consumption of green energy represents a mere $1 \%$ of the energy consumption in an average-sized community, but many local communities do not have a local energy cooperative. The renewable energy that is realized is often restricted to some renewable electricity (solar panels); there is no, or very little, renewable heat or renewable gas. The local cooperatives operate as a retail organization selling green energy under the license of one of the established energy suppliers in the energy market. Recently, the first new local energy cooperatives with their own license were founded to accommodate this new form of energy company. The gradual expansion of the number of clients or the production of renewable energy by these organizations in the years to come could take the local renewable energy cooperatives that are not specialized in wind energy out of the early stage of development.

\section{Case studies}

\section{Background}

Our frontrunner local energy cooperatives were established in different periods: Deltawind (1989), Texel Energie (2007), Lochem Energie (2010), and Grunneger Power (2012). The background characteristics of home/facility areas these cooperatives are different (see Table 1). Three of them are located in rural areas with many townships, whereas one is in an urban area. Two of the cooperatives are surrounded by water (Deltawind on a peninsula and Texel Energie on an island), and the other two are situated on land. The rural cooperatives are located in areas of natural beauty, with nice landscapes attractive to tourism.

The process to establish the cooperatives was broadly similar in all cases. Several people were enthusiastic about the production of local renewable energy and asked others

Table 1 Background characteristics of the local cooperatives' home/facility areas

\begin{tabular}{|c|c|c|c|c|}
\hline & Deltawind & $\begin{array}{l}\text { Texel } \\
\text { Energie }\end{array}$ & $\begin{array}{l}\text { Grunneger } \\
\text { Power }\end{array}$ & $\begin{array}{l}\text { Lochem } \\
\text { Energie }\end{array}$ \\
\hline $\begin{array}{l}\text { Surface area (land/water) } \\
\text { in square } \mathrm{km}\end{array}$ & $262(160)$ & $\begin{array}{l}170 \\
(302)\end{array}$ & $84(0)$ & $213(0)$ \\
\hline Type of landscape & Rural & Rural & Urban & $\begin{array}{l}\text { Rural/ } \\
\text { urban }\end{array}$ \\
\hline Type of area & Peninsula & Island & Land & Land \\
\hline Number of townships & 14 & 22 & 14 & 12 \\
\hline Local government & $\begin{array}{l}\text { Goeree- } \\
\text { Overflakkee }\end{array}$ & Texel & Groningen & Lochem \\
\hline Regional government & $\begin{array}{l}\text { South } \\
\text { Holland }\end{array}$ & $\begin{array}{l}\text { North } \\
\text { Holland }\end{array}$ & Groningen & Gelderland \\
\hline
\end{tabular}

to share this idea. A small group elaborated the idea and realized that success was possible. Because the concept of a local energy cooperative specializing in renewable energy is recognized as useful and inspiring, the first steps were relatively easy. Volunteers offered their services, and energy consumers joined the club. Each additional step was welcomed by others, and the organization started to grow.

The initiators did not see how their ambition could be realized in the context of the existing energy sector. Their sense of that market's failure was strong, and consequently, a new organization was unavoidable. After extensive deliberations, the groups decided to create a new legal entity for the local energy organization, i.e., a non-profit local cooperative. The initiators and other early participants formed the hard core of each new cooperative. Local media reported on it, and the group of participants and members grew step-by-step. Local government welcomed the initiatives, communicated with the groups, and started collaboration.

Each of the local cooperatives engaged tens of volunteers to support service delivery of their output. The energy cooperatives had various ways to connect to their adherents. Membership was an easy way of connecting. Deltawind and Texel Energie required payment of a membership fee to join the cooperative. Texel Energie had 3200 members who bought shares in it for an amount of 350,000 Euro in 2013, and Deltawind had 1566 members who invested 3.9 million Euros through loans. Lochem Energie and Grunneger Power had 400 and 681 members, respectively (end 2013). These cooperatives do not sell shares or ask for loans as they become member of the cooperative.

\section{Services of the energy cooperatives}

The energy cooperatives offer more or less the same concept and a similar type of service to their adherents, although each has its own profile:

\section{Energy services}

Deltawind does not provide green energy, but between 2 and $7 \%$ of the households in the 14 townships participate (end 2013: 1566 members) in the energy cooperative. In a few years, Texel Energie has become one of the largest energy suppliers to the island, with an estimated 3400 clients that consume its renewable electricity or gas (end 2013). Lochem Energie and Grunneger Power provide energy to 130 and 523 clients, respectively (end 2013). This is about $1 \%$ of the households in Groningen and Lochem.

\section{Production of renewable energy or installation of renewable energy by small-scale energy users themselves}

The production of renewable energy by the local cooperatives concerns renewable electricity (solar panels, wind 
turbines). Renewable heat or renewable gas was not produced by the local cooperatives. However, Texel is interested in renewable gas and heat, and has developed projects for them that will be realized shortly. Deltawind invested in 22 wind turbines, whereas Texel Energie buys wind energy from one local producer. All the cooperatives are active with solar panels with one or more groups such as households, association of owners and tenants, and SMEs. In some cases, the cooperative is the owner of the solar panels and sells the electricity (Deltawind) or rents the solar energy to tenants or others (Lochem Energie). In other cases, the cooperatives support procurement by their members who buy the solar panels themselves. Deltawind's renewable energy production involves 22 wind turbines and a solar park with 2960 solar panels. The electricity needs of all households on Goeree-Overflakkee are completely covered by the wind turbines and the Deltawind solar park. The number of solar panels installed after consultation or with the help of Deltawind is not recorded. Statistics show that the number of solar panel systems of households on Goeree is twice as much as the national average. Solar panels provide around $3 \%$ of the electricity needs of the households in the facility area. In Groningen and Lochem, an estimated $25 \%$ of the clients of Grunneger Power and Lochem Energie have opted for solar panels. The local cooperatives reported that they contributed directly or indirectly to the installation of solar panels in Lochem (1103) and Groningen (1608). Since Grunneger Power's and Lochem Energie's share of clients is relatively small (around $1 \%$ ), so too is the contribution to electricity production in the facility area by the local cooperatives' clients.

Texel Energie reported an involvement in installation of solar panels on different buildings (in sum: 704 panels) after it had given advice and help. The number of solar panels for households to which they directly or indirectly contributed was not recorded. Statistical data from Liander show that on Texel, more than three times as many solar panel systems are installed than the national average, covering around $6 \%$ of the electricity needs of households in the facility area. The supportive volunteers' enthusiasm for solar panels, and the education, and advice from Texel Energie and its partners have contributed to this result, according to the interviewees.

\section{Advice, education}

The volunteers in the local cooperatives offer personal advice about different aspects of energy conservation and renewable energy (for example, an energy conservation scan, a heat use scan). In some cases, information evenings are organized. The services of the cooperatives include technical and commercial advice, support of the procurement process, installation, and maintenance (using preferred suppliers), and financial arrangements (loans, subsidies, rent).
Some of the local cooperatives are involved in education activities to the local community in general (Lochem) or give lessons to primary or secondary schools (Deltawind). Deltawind participates in local socio-cultural projects on Goeree.

\section{Research and development}

Local cooperatives are actively involved in research and innovation. The cooperatives are continuously looking for new services to provide. With the prospect of changes in policy or law in mind, the cooperatives are developing new plans and services to install solar panels. In addition, the feasibility of renewable energy projects is being investigated, often in collaboration with local governments. Two of the cooperatives are actively involved in smart grid research projects that aim to improve energy management at home. The research is undertaken by research institutes or partners, and the local cooperatives enroll participants for the experiments (Texel Energie: 300 participants, Lochem Energie: 30 participants). In addition, one cooperative (Lochem Energie) is participating in an experiment with smart energy displays.

\section{Organization of the local cooperatives}

The organization of the local energy cooperatives was a rather open process in which people became involved step-by-step. It was an improvised process led by the inspired initiators who wanted to produce and consume local renewable energy. The initiatives without exception chose the legal entity of a non-profit cooperative. This choice was induced by an aversion to private energy enterprises in the energy sector. The choice of cooperative as legal entity shows that these organizations were established by people and for people. In order to build up a professional organization, several employees were hired. In 2013, Deltawind had seven employees (4.4 fte); Texel Energie, six employees (5 fte); Grunneger Power, two employees (2 fte); and Lochem Energie, two employees $(<1 \mathrm{fte})$. As already mentioned, the local cooperatives are supported by tens of volunteers that provide advice or other services. The cooperative option has become the model for the establishment of new local energy initiatives. In this legal entity, the members are decisive in all important matters such as the policy headlines and composition of the board.

\section{Local cooperatives and their networks}

The production and delivery of green energy requires collaboration with many other organizations. Table 2 outlines each of the operations' networks of private, semi-public, and public partners. As the freshly established local cooperatives did not produce energy, it was necessary to buy green energy and subsequently deliver it to their clients. The local cooperatives chose at the 
Table 2 Networks of the local energy cooperatives

\begin{tabular}{|c|c|c|c|c|}
\hline & Deltawind & Texel Energie & Grunneger Power & Lochem Energie \\
\hline \multirow[t]{4}{*}{ Energy distribution } & \multirow[t]{4}{*}{ - No energy distribution } & $\cdot \mathrm{HVC}$ & - Trianel & - Trianel \\
\hline & & - Greenchoice & - Sepa-Green/EABO & - Eneco \\
\hline & & - DGB & - NLD-Energy & \\
\hline & & - DE Unie & & \\
\hline \multirow[t]{2}{*}{ Energy production } & - E.on & \multirow[t]{2}{*}{ - TEzon, TEgas, TEjoule } & \multirow[t]{2}{*}{ - Solar cooperative } & \multirow[t]{2}{*}{ - Not applicable } \\
\hline & - Three limited companies & & & \\
\hline \multirow[t]{2}{*}{ Preferred suppliers } & - Greenchoice & \multirow[t]{2}{*}{ - Installation firm } & \multirow[t]{2}{*}{ - Installation firms (5) } & - Eneco \\
\hline & - Eneco-Wind & & & - Installation firms (4) \\
\hline \multirow[t]{2}{*}{ Social housing organizations } & \multirow[t]{2}{*}{ - No } & - Collaboration & - Collaboration & - Collaboration \\
\hline & & - Woontij & - Leeuwenborgh & - IJsseldal Wonen \\
\hline \multirow[t]{2}{*}{ Local government } & - Independent & - Independent & - Independent & - Independent \\
\hline & - Collaboration & - Involved & - Involved & - Involved \\
\hline
\end{tabular}

start not to buy green energy from the large energy cooperatives. The energy cooperatives not specialized in wind energy changed their preferred green energy provider for a variety of reasons. Some of the providers did not produce electricity as well as gas (HVC), were not flexible enough (Greenchoice), or went bankrupt (Trianel). After several years, two local cooperatives (Texel Energie, Grunneger Power) opted for a new organization with its own license to deliver green energy (DE Unie, NLD Energie). Independence was seen as an important advantage, and becoming independent seems to be their final choice after an elaborate search process. In the end, Lochem Energie chose one of the large energy cooperatives to deliver green energy (Eneco). The position of Deltawind is different from that of the other energy cooperatives. Consequent to mergers and acquisition processes, the energy production organization E.on has become a client for Deltawind's wind energy.

Some of the local energy cooperatives established new organizations for the production of renewable energy for fiscal and financial reasons. The autonomy of these private enterprises is a condition sine qua non for investors. One wind turbine park was developed in collaboration with a private company established by one of the Deltawind founders. In addition, Texel Energie decided to establish several private enterprises for their renewable energy production (TEzon, TEgas, TEJoule). One of the two other local cooperatives decided to establish an energy cooperative for collective solar panels in order to avail of tax exemptions.

The local cooperatives started partnerships with local government, and three of them collaborate on solar panel projects with social housing cooperatives, whose involvement was problematic for a long time because of the split incentive between investor and beneficiary. The energy cooperatives developed new services to solve these problems. Now, tenants can participate in solar panel projects operated by collectives in Groningen and Lochem. In addition,
Lochem Energie invites tenants to rent solar panels for their own homes.

The collaboration with local governments is based on coinciding missions and goals. The local governments have a mission to achieve an energy neutral status in their territory, and the local energy cooperatives are established to produce renewable energy. Local governments respect the cooperatives' independent identity. The sympathy of local governments for the energy cooperatives is manifest in the way they make themselves accessible to the cooperatives, which have taken on some of the role that local governments played on the energy market for decades.

The partnership with local government has proven to be very important for the local energy cooperatives. Local governments facilitate the cooperatives in a variety of ways such as support for the establishment of technical feasibility studies on renewable energy. They give financial support to the cooperatives through loans, subsidies, and other support. The partnership supports new projects undertaken by the cooperatives because renewable energy requires a supportive local energy policy, and legal and regulatory support.

\section{Mission or perspective of the local energy cooperatives}

The missions of the energy cooperatives have many similarities when formulated in abstract statutory terms. The idea is to enhance energy conservation and to produce local renewable energy. However, the individual local cooperatives have differing perspectives.

- Deltawind has already succeeded in producing electricity for the inhabitants of Goeree-Overflakkee. When another 22 wind turbines are installed, the peninsula will be an exporter of wind energy. The Deltawind wind turbines are integrated in national plans for wind energy. 
- In 7 years, Texel Energie has become one of the largest energy suppliers to the island. Its plans to produce renewable gas and renewable heat are a signification contribution towards the community's long-term objective: energy independence.

- Grunneger Power and Lochem Energie have a relatively small clientele, and their objective is to grow and to ensure a solid financial basis for their organizations. Grunneger Power chose to focus on solar energy, and this limits the potential for energy production.

\section{Energy transition in local energy cooperatives (research question 2)}

Deltawind At Goeree-Overflakkee, a radical energy transition took place because of Deltawind. The cooperative does not sell green energy but produces enough renewable electricity for the 15,000 households on the peninsula by wind turbines and a solar park. Furthermore, it has enhanced the production of renewable energy by solar panels, resulting in an additional contribution to renewable energy. Deltawind will produce more renewable energy by wind turbines in the near future and will contribute to the electricity needs of other parts of the Netherlands.

Texel Energie Texel Energie has caused a radical energy transition on the island. An estimated $55 \%$ of all households on the island buy green energy from the new energy cooperative, and around $16 \%$ of the other households buy green energy from the other energy suppliers. In sum, $71 \%$ of the households on the island use green energy, thereby giving a market pull to this type of energy. Furthermore, a large proportion of the households on Texel produce renewable energy with solar panels; around $6 \%$ of the electricity needs of households on the island is covered by these systems. So far, Texel Energie does not produce renewable gas and heat, but plans to do so have been developed.

Grunneger Power An energy transition was not realized in Groningen, Haren, and Ten Boer. The number of green energy consumers is insufficient, and not enough renewable energy electricity is produced. So far, no plans for renewable gas and heat have been developed.

Lochem Energie An energy transition was not realized in Lochem because the number of inhabitants using green energy has not changed enough. The same holds for the production of renewable energy electricity. So far, no plans for renewable gas and heat have been developed.

\section{Energy producers and customers: comparative advantage, complexity, and compatibility (research question 3) Deltawind}

Comparative advantage, complexity, and compatibility From the start in 1991, Deltawind found local customers who were interested in wind energy because they saw the product as having a comparative advantage over other energy sources. The local energy cooperative (EMGO) was only mildly interested in the new technology. However, the idea of local production by Goeree inhabitants was convincing enough for the local energy provider. In return for buying the wind energy, EMGO asked for new customers to consume the product. For Deltawind's later customer (E.on), the comparative advantage of wind energy was obvious because the popularity of "home-grown" green energy is growing. The ongoing societal discussion about the authenticity of green energy is an additional comparative advantage for Deltawind.

Neither is complexity an issue because wind energy is as useful as the energy from a coal-fired power station. The transportation process is not more difficult for wind energy because the same infrastructure is used. The use of wind energy was not obstructed by high complexity and compatibility, and the comparative advantages were clear and became more evident over the years.

\section{Texel Energie, Grunneger Power, Lochem Energie Comparative advantages}

Concept From the start, the local energy cooperative idea offered an attractive new concept for energy conservation and renewable energy. The concept comprises several products (e.g., green energy, renewable energy) as well as the cooperative's democratic structure. The idea to further develop the cooperative is an intrinsic and intriguing part of the new concept. For participants, this concept has strong comparative advantages relative to large energy companies on the Dutch market. The comparative advantages of the local cooperatives are clear; however, they seem to attract a very motivated but relatively small number of customers. The popularity of the concept on Texel seems to be the exception to the rule. The cooperative responds to the island's idea of autonomy and cutting the cable for energy transport from the mainland. The beautiful nature and landscape are additional reasons to support renewable energy as the ultimate natural way of energy production.

Free and personal advice In comparison to other energy delivery companies, the local cooperatives offer free and accessible one-to-one personal advice about domestic energy conservation, heat leakages at home, the advantages of insulation, and sustainable lights. The free support for the procurement of solar panels is an 
additional advantage. The accessible advice of volunteers engaged by the cooperatives supports the idea of commitment. Although energy is no longer the low interest product that it used to be, many people are not interested in free advice about energy conservation or other issues.

Green energy, renewable energy A comparative advantage of the local cooperatives is that real green energy is provided. Since much of the marketed green energy is "grey" green energy, the added value of real green energy from the local energy cooperatives is clear enough. For most people, the energy price is by far the most important determining factor in the choice of an energy delivery organization [8]. In recent years, green energy organizations' market share has decreased nationwide, but, apparently, the clients of the local energy cooperatives are motivated to buy real green energy from the local energy cooperative. The perceived comparative advantage of green energy is so strong that even the bankruptcy of Groningen's and Lochem's licensed energy supplier, and the uncertainties about energy delivery that resulted from this, did not lead clients to choose another energy supplier. This shows that the clients appreciate the green energy of their local cooperative much more than the services of other suppliers. Furthermore, more than elsewhere, the local cooperative on Texel is seen as part of the community; it is an expression of the inhabitants' cultural identity, which values autonomy highly. The large number of clients on the island shows the perceived comparative advantage of the energy services of "their" Texel Energie.

\section{Complexity}

The concept of the local energy cooperatives (not specialized in wind energy) and some of the products that they provide are relatively complex. The idea of local cooperatives is to reduce energy needs and to produce as much renewable energy as possible for the remaining energy needs. The possibilities for producing renewable energy need careful consideration by clients and so do the measures for energy conservation. The high complexity is probably an obstacle to attracting large groups of customers to the local energy cooperatives. Participation in the three energy cooperatives is more demanding than using energy from a traditional supplier. Even though people are nowadays more interested in energy than before and switch to new providers relatively easily, participation in the local energy cooperatives is relatively complex. For Texel, complexity is not a very limiting factor, because local commitment to the island is strong. Choosing Texel Energie in this case means not only choosing green energy but also choosing the island and its local identity.

\section{Compatibility}

The energy behavior of the three cooperatives' customers is not easily compatible with much of the normal energy behavior of a standard household. In addition to the complexities in energy consumption and production, the cooperatives require active involvement. This involvement might include participation as a volunteer to provide support for the procurement of renewable energy installations. Membership of the cooperative requires attendance at the cooperative's annual meeting or other gatherings. The choice to produce renewable energy locally is the start of a strategy that demands an active search for different technical options and tests of their feasibility. The need to innovate is apparent in the energy cooperatives' participation in research projects that aim to find new ways to manage the consumption of renewable energy. Compatibility with normal energy use is low, but at the same time, this represents a comparative advantage to some consumers.

\section{Potential to develop or up-scale innovations (research question 3) \\ Deltawind}

Incentive to innovate and incentive to reveal innovation Innovation is an important aspect of Deltawind's credentials as it was established to bring about change in the energy production sector. The idea of producing renewable energy and being self-sufficient in energy was a revolutionary idea and a strong impetus to innovate. From the start, the cooperative has added to and upgraded its assets, i.e., wind turbines, over the years. The innovation in the past years concerned, for example, the technology of the turbines and the size of the production location. Deltawind is supported by a large group of members that live on the peninsula. The installation of the wind turbines has therefore been accepted by the local community. Deltawind's open attitude and the visibility of the wind turbines exemplify the cooperative's strong urge to communicate its intentions, plans, and innovation to others. Obviously, in this case, there is no risk of the local cooperative's ideas remaining undiscovered in the ranks of the Deltawind volunteers.

\section{Competitive advantages}

Deltawind is in a good position to produce additional renewable energy through wind turbines on Goeree. The organization is strongly rooted in the local community on the peninsula. It seems to be no coincidence that the second large wind cooperative is established on an island. Furthermore, the price of the energy produced by the wind turbines is attractive in comparison to other forms of renewable energy and acceptable in relation to fossil fuels. The cooperative's solid financial position enables it to invest in wind turbines. As a non-profit 
organization, Deltawind is a more credible protagonist of renewable energy than private energy companies. Its plea for renewable energy is based on a societal assessment of the need for renewable energy. It is therefore understandable that one of the energy companies that want to build the wind turbines is another regional cooperative.

Deltawind is able to attract local inhabitants to become members of the cooperative and has a good position in relation to other energy producing organizations. The limiting factor for up-scaling wind energy production is not so much the competition from other energy organizations as societal acceptance in and outside Deltawind. The enormous size of an additional wind park is not acceptable for everyone. The recent initiative to install additional wind turbines, about which it consulted with its members, is probably an acceptable new goal for the cooperative. The original goal of self-sufficiency for Goeree has been realized, but the wind turbines are seen by many as a valuable technology for others outside the area as well.

\section{Texel Energie, Grunneger Power, Lochem Energie} Impetus to innovate and incentive to reveal innovation Local cooperatives were established because of dissatisfaction with large energy companies. The cooperatives' members share the idea of producing local renewable energy and an economical use of energy. The new concept has been developed by and for the members, whose active participation in research and development projects exemplifies their commitment to innovative services and products.

Local cooperatives have a strong incentive to reveal their new concepts, services, and products. Their mission to change energy consumption and production demands an open attitude. The cases show proactive cooperatives that attract new members, energy consumers, investors, and collaboration partners to their organization. The cooperative is an appropriate legal entity to include as many different groups and partners as possible. The need to attract collaborating partners is partly induced by the small size of the organization. A small professional staff in the local cooperatives complemented by volunteers demands additional expertise and skills to fulfill the cooperatives' ambitions. The energy cooperatives prove very successful in connecting with partners and societal groups. The proactive attitude towards new partners is also necessary to secure the financial foundations of the private cooperatives. Public as well as semi-public and private partners are important investors in the local cooperatives.

\section{Competitive advantages}

The competiveness of any supplier of energy to smallscale users is continuously on the line because the market has been liberalized. This means that consumers are at liberty to choose another energy supplier. This offered the local energy cooperatives the chance to start their green energy delivery using the facility that enables consumers to switch. The price of green energy is higher than the price of energy from fossil fuel. The following competitive factors influence the considerations of the local energy cooperatives' clients:

Committed clients Local cooperatives are built on members' enthusiasm, clients' loyalty, and a strong commitment to renewable energy. The great number of energy cooperatives and the great number of participants demonstrate the societal support for this idea. Even the bankruptcy of a green energy supplier did not change clients' commitment. The social cohesion on Texel supports the commitment of its members, and it seems no coincidence that the second large energy in the Netherlands cooperative is also located on an island.

Promising coalitions Local cooperatives share the same goals concerning renewable energy as regional and local governments and social housing cooperatives. Collaboration in projects with local and regional partners is based on coinciding goals. Partnership with local government is promising because of the access to legal licenses, spatial reservations for renewable energy, and ownership of the energy network.

Social acceptance The collaboration between local energy cooperatives and local government provides energy projects a legitimacy that projects of other organizations lack. Projects like a solar park of solar panels (Lochem), solar panels on the town hall (Lochem) and tenants' houses (Groningen), and solar panels in the social housing sector (Lochem, Groningen) are realized in collaboration between energy cooperatives and local government.

\section{Competitive disadvantages}

Governance power The non-commercial spirit and the participation of volunteers is an important asset but also a weakness. Supplying an energy market demands technical knowledge, a professional organization, and entrepreneurship. The bankruptcy of the energy supplier in Lochem and Groningen shows cooperatives' vulnerability.

Financial constraints Local cooperatives employ a small staff and a relatively large workforce of volunteers. In order to be competitive on this market, the local organizations should invest in renewable energy projects, but large energy companies have much larger investment budgets [6]. Investment in (collective) renewable energy is difficult because of a lack of resources. 
Energy networks Dutch energy networks have been built over the course of decades and are designed for the central production of energy [5, 17]. Local production of renewable energy demands a change in the local energy infrastructure. Two local energy cooperatives anticipate problems with local energy infrastructure and are participating in experiments to test new energy management systems that accommodate the supply of, and demand for, renewable energy.

Legislation The energy market is a liberalized but regulated market that provides rules for the production, transport, and delivery of energy. The relationship between local cooperatives and local government is potentially challenging or even problematic [38]. Local governments combine different roles such as shareholder in old energy suppliers, initiator and/or shareholder of new energy cooperatives, investor in cooperatives, and collaborating partner in many projects. Local governments run the risk of violating European and national rules concerning the energy market.

\section{Conclusions}

\section{Energy transition or not?}

The statistics on the performance of the Netherlands in renewable energy use, indicating a relatively small amount of final energy consumption from renewable energy sources on the one hand and the establishment of many local energy cooperatives specializing in renewable energy on the other hand, are not contradictory. The establishment of about 91 local energy cooperatives (not specialized in wind energy) in the last 7 years is a niche innovation in an early stage of development and not yet integrated in the energy sector. The local energy cooperatives have settled as an undercurrent in Dutch society and the energy market. The establishment and development of 16 wind energy cooperatives in the last three decades is an example of a niche innovation in a mature development stage that was successfully integrated in the energy production system (regime). Apparently, the contribution of the wind cooperatives was not sufficient to provide a better score for the Netherlands in energy statistics.

However, the contribution of renewable energy consumption and production appeared to be successful in two of the four case studies of local communities. The case studies demonstrated that on Goeree-Overflakkee and Texel, an energy transition or radical innovation took place, whereas none occurred in Groningen and Lochem. Deltawind already produces enough renewable electricity (wind turbines and solar panels) for all 15,000 households on the peninsula. The realization of another 22 wind turbines will further add to the production of renewable energy. Texel Energie can also be seen as the initiator of an energy transition because of its large number of green energy consumers and the substantial production of green electricity by households. The production of renewable gas and heat in the near future will give an extra boost to energy production on the island. The number of green energy consumers in Groningen and Lochem is but a small proportion of normal energy consumption, and the production of renewable energy is limited to renewable electricity (especially solar panels), and renewable gas and heat are not yet produced.

If and to what extent the concept of the local cooperatives can contribute to a transition towards production and/or consumption of renewable energy in the Netherlands is summarized in Table 3. The Deltawind concept is relatively attractive for clients or buyers in comparison to the local energy cooperatives not specialized in wind energy. Active participation in the energy cooperative appeals to a group of enthusiastic consumers, but, for many others, membership of this cooperative is too complex and demanding. The use of wind energy is very simple and compatible since the same energy infrastructure is used. It is not likely that the not-wind energy cooperatives will cause an energy transition or radical innovation in the near future.

The concept of the wind energy cooperative, Deltawind, has a better position on the energy market than that of the other local energy cooperatives. The organization is strongly rooted in the local community, the price of its wind energy is acceptable, and social acceptance of the organization is strong. Deltawind was able to build wind turbines without significant protest from citizens or environmental groups. The three energy cooperatives not specialized in wind energy sell relatively expensive green

Table 3 Potential for change of renewable energy production and consumption by local wind and energy cooperatives in the energy sector

\begin{tabular}{|c|c|c|c|}
\hline \multicolumn{2}{|l|}{$\begin{array}{l}\text { Potential energy } \\
\text { cooperatives }\end{array}$} & \multirow{2}{*}{$\begin{array}{l}\text { Deltawind } \\
+\end{array}$} & \multirow{2}{*}{$\begin{array}{l}\text { Texel Energie, } \\
\text { Grunneger } \\
\text { Power, Lochem } \\
\text { Energie } \\
-/+\end{array}$} \\
\hline $\begin{array}{l}\text { Energy transition/ } \\
\text { radical innovation in } \\
\text { facility area }\end{array}$ & & & \\
\hline \multirow{3}{*}{$\begin{array}{l}\text { Success conditions } \\
\text { radical innovation } \\
\text { (relation producer- } \\
\text { consumer) }\end{array}$} & $\begin{array}{l}\text { Comparative } \\
\text { advantage of the } \\
\text { concept, services }\end{array}$ & + & $+/-$ \\
\hline & Complexity & + & - \\
\hline & Compatibility & + & - \\
\hline \multirow[t]{3}{*}{$\begin{array}{l}\text { Success conditions } \\
\text { bottom-up innovations }\end{array}$} & $\begin{array}{l}\text { Incentive to } \\
\text { innovate }\end{array}$ & + & + \\
\hline & Incentive to reveal & + & + \\
\hline & $\begin{array}{l}\text { Competitive } \\
\text { advantage in } \\
\text { relation to other } \\
\text { suppliers/producers }\end{array}$ & + & - \\
\hline
\end{tabular}


energy and produce some renewable energy by solar panels. Time will tell whether these local energy cooperatives will be able to maintain the commitment of their clients and use their social acceptance and their partnerships with public and semi-public organizations for further development. Competitors in the energy sectors have the advantage in terms of governance power, financial resources, and the existing energy infrastructures. The balance between competitive advantages and disadvantages will probably be influenced by the national government's choices about whether or not to stick with the privatized market regime.

The Texel Energie example demonstrates that, under specific circumstances, a local energy cooperative is able to cause an energy transition in its facility area despite using a difficult concept. The large number of small townships on the island and the abundance of space, wind, and sun are favorable circumstances for the production of renewable energy. The cooperative responds to the island's idea of autonomy and of no longer having to import energy from the mainland. The Deltawind example shows a powerful concept that caused a radical innovation in energy production on Goeree-Overflakkee. However, it is not certain that this concept can be easily reproduced in all other local communities. The active or even passive support of citizens and social groups on Goeree-Overflakkee seems to be rather the exception than the rule. In many other local communities, serious obstacles arise such the acceptance of wind turbines, spatial planning problems, and legal procedures and protest [35].

The successes of Deltawind and Texel Energie in terms of contribution to energy transition or radical innovation are obviously not a guarantee for the same results elsewhere. The uniqueness of the circumstances in the case studies prevents easy reproduction of the success mechanisms of an innovative concept. The idea of up-scaling the experiences of niche innovations to an existing regime is probable too simplistic $[39,40]$. It is therefore too early to interpret these examples as a revolution in disguise in the Netherlands. The case studies in this article give an indication of the potential of several new concepts for energy transition, as well as obstacles that must be tackled. Because of the uniqueness of circumstances, additional case studies will probably not result in readymade solutions to contribute to energy transitions or radical innovations. However, knowledge about other energy transitions or radical innovations and about additional successful mechanisms in other local energy cooperatives is needed. A combination of success mechanisms in different case studies can probably facilitate the switch towards a zero energy society.

\section{Competing interests}

The authors declare that they have no competing interests.
Authors' contributions

JAMH contributed to the design and carried out the data collection and analysis. JFMK contributed to the theoretical background, the analysis, and conclusions. Both authors read and approved the final manuscript.

\section{Acknowledgements}

We would like to acknowledge Catherine O'Dea for her services as language editor as well as the participants in our workshop (Smart Energy System Transition in Cities and Regions) for their feedback on a concept version of this article during the ESEIA conference held on 24 and 25 April 2014 at the University of Twente.

\section{Author details}

${ }^{1} \mathrm{QA}+$ Research and Consultancy in Leiden, Galileïweg 8, 2333BD, Leiden, The Netherlands. ${ }^{2}$ Department of Public Administration, Faculty of Social Sciences, Erasmus University Rotterdam, P.O. Box 17383000DR, Rotterdam, The Netherlands.

Received: 18 December 2014 Accepted: 11 May 2015

Published: 21 May 2015

\section{References}

1. Eurostat Newsrelease (2014) Renewable energy in the EU28 (37/2014). Available via Eurostat Press Office, http://ec.europa.eu/eurostat/documents/ 2995521/5181358/8-10032014-AP-EN.PDF/91350d4a-4b57-4833-b9f0-32cfe0 a6d360?version=1.0. Accessed 19 February 2015

2. European Commission (2013) Innovation scoreboard 2013. Brussels. doi:10.2769/72530. Accessed: 15 May 2015

3. Buitelaar S (2013) AL 500 lokale energie-initiatieven. http://www.binnenlands bestuur.nl/ruimte-en-milieu/nieuws/al-500-lokale-energie-initiatieven.9165637. lynkx. Accessed 19 February 2015

4. Planbureau voor de leefomgeving (2011) De Energieke Samenleving, Op zoek naar een sturingsfilosofie voor een schone economie. PBL, Den Haag

5. Afman MR, Bles M, Schepers BL, Wielders LML (2014) Electriciteitsleveranciers in kaart.. CE, Delft

6. Afman MR, Bles M, Schepers BL, Wielders LML (2014) Elektriciteitsleveranciers in kaart (referentierapport) CE, Delft

7. Consumentenbond, Greenpeace, Hivos, Natuur \& Milieu, Vereniging Eigen Huis, WWF, Wise (2014) Onderzoek duurzaamheid elektriciteitsleveranciers. Utrecht. Available via Consumentenbond. http://www.consumentenbond. $\mathrm{nl} /$ tests/bestanden/woning-huishouden/onderzoek-duurzaamheid-elektricite itsleveranciers2014.pdf. Accessed 19 February 2015

8. Marketresponse (2014) Stand van zaken op de energiemarkt. Available via autoriteit consument en markt, https://www.acm.nl/nl/download/ publicatie/?id=12909. Accessed 12 February 2015

9. Krozer Y (2014) Smart grid and EU 27 countries policy. Paper presented at the ESEAl conference Twente University, Enschede, 24-25 April 2014 Krozer, Y (2014) Smart Grid and EU 27 countries policy. In: European Sustainable Energy Innovation Alliance conference; Enschede, 24-25 April 2014, 24-04-2014 - 25-04-2014, Enschede

10. Association of Energy Companies in the Netherlands and Association of Network Operators in the Netherlands (2012) Energy in the Netherlands 2011. Den Haag/ Arnhem. Available via Windunie. http://www.windunie.nl/Documents/Energie-inNederland-2011rapport.pdf Accessed 19 february 2015

11. Ministerie van Economische Zaken, Landbouw \& Innovatie (2011), Energierapport 2011, Den Haag. Available via Rijksoverheid. http://www.rijksoverheid.nl/ bestanden/documenten-en-publicaties/rapporten/2011/06/10/ energierapport-2011/energie.pdf. Accessed 19 february 2015

12. Schöne S (2014) Groene stroomconsumenten hebben recht op geloofwaardig product. Energiegids. Het vakblad over energie-efficiency 5:24-5

13. Ministerie van Economische Zaken (2005) Nu voor later. Staatsuitgeverij, Den Haag

14. Ministry of Economic Affairs, Agriculture and Innovation (2011), Available via Dutch parliament, http://www.tweedekamer.nl/ zoeken? gry $=2011$ Z07455\%2F2011D19360\&clusterName=Overige +Kamerstukken\&Type=Kamerstukken\&fld_prl_kamerstuk=Overige +Kamerstukken\&fld_prl_soort=Brief+commissie+aan +bewindspersoon\&srt=score\%3Adesc\%3Anum. Accessed 23 May 2015

15. Raad SE (2013) Energieakkoord voor duurzame groei. Sociaal Economische Raad, Den Haag 
16. Ministerie van Volkshuisvesting, Ruimtelijke Ordening en Milieubeheer, Een wereld en een wil werken aan duurzaamheid (2001). Available via RIVM, http://www.rivm.nl/bibliotheek/digitaaldepot/NROM2001NMP4.pdf. Accessed 19 February 2015

17. Rotmans J (2012) In het oog van de orkaan. Aeneus, Boxtel

18. Loorbach J (2010) Transition management for sustainable development: a prescriptive, complexity-based governance framework. J Policy Adm Inst 23:161-83

19. Koppenjan J, Frantzeskaki N, Loorbach D, Charles MB, Ryan N (2012) Introductory editorial. Int J Sustain Dev 15:1-18

20. Verbong G, Loorbach D (2012) Introduction. In: Verbong G, Loorbach D (eds) Governing the energy transition? Routledge, New York/London

21. Planbureau voor de leefomgeving (2014) Energiecoöperaties, Ambities handelingsperspectief en interactie met gemeenten. PBL, Den Haag

22. Lundvall BA (2010) National innovation systems of innovation, towards a theory of innovation and interactive learning. Anthem Press, London

23. Lintsen H (2005) Made in Holland, Een techniek geschiedenis van Holland. Walburg Press, Zutphen

24. Rogers EM (1983) Diffusion of innovations. New York Free Press, New York

25. Hekkert M, Ossebaard M (2010) De innovatiemotor, het versnellen van baanbrekende innovaties. Van Gorcum, Assen

26. Egyedi TM, Vrancken JLM, Ubacht J (2002) Inverse infrastructures: coordination in self-organizing systems. Available via Delft University of Technology, http://www.tbm.tudelft.nl/fileadmin/Faculteit/TBM/Over_de_ Faculteit/Afdelingen/Afdeling Infrastructure Systems and Services/ Sectie_Informatie_en_Communicatie_Technologie/medewerkers/tineke_ egeydi/publications/doc/siit2007_Inverse_Infra.pdf. Accessed 19 February 2015

27. Von Hippel E (2009) Horizontal innovation networks - by and for users. Available via Massachusetts Institute of Technology, http://ssrn.com/ abstract=1411719. Accessed 19 February 2015

28. Ministerie van Infrastructuur en Milieu, Rijkswaterstaat (2013) Handreiking De rol van gemeenten bij lokale duurzame energie-initiatieven. The Hague. Available via Rijkswaterstaat. http://www.rwsleefomgeving.nl/onderwerpen/ lokaal klimaatbeleid/publicaties/downloads/handreiking-rol/ Accessed 20 february 2015

29. Rijksoverheid (2013) Visie lokale energie. Available via Rijksoverheid, http:// www.rijksoverheid.nl/documenten-en-publicaties/rapporten/2013/11/08/ visie-lokale-energie.html. Accessed 19 February 2015

30. Wielders LML, Cheriff S, Schepers BL (2014) Groenestroomklanten voor de consumentenmarkt. CE, Delft

31. The database of regional distribution systems operators is a register of production installations that are reported by energy users. Available via a website of regional distribution system operators. http://www.energie leveren.nl. Accessed 19 February 2015

32. Oskam HP (2011) Local sustainable energy companies and municipal involvement: designing a framework for municipal involvement. Available via Delft Technical University, http://www.tbm.tudelft.nl/fileadmin/Faculteit/ TBM/Over_de_Faculteit/Afdelingen/Afdeling_Multi_Actor_Systems/ Sectie_Beleid,_Organisatie,_Recht_en_Gaming_POLG/Onze_afgestudeer den/doc/HansPeterOskam_Thesis.pdf. Accessed 19 February 2015

33. Oteman M, Wiering M, Helderman JK (2014) The institutional space of community initiatives for renewable energy: a comparative case study of the Netherlands. Germany and Denmark, Energy, Sustainability and Society 4:11

34. Verbong G, Van Selm A, Knoppers R, Raven R (eds) (2001) Een kwestie van lange adem, De geschiedenis van duurzame energie in Nederland. Aeneas Uitgeverij, Boxtel

35. Agterbosch S (2006) Empowering windpower: on social and institutional conditions affecting the performance of entrepreneurs in the wind power supply market in the Netherlands. Dissertation, University of Utrecht

36. Oskam HP (2012) Rol gemeenten in lokale energiesector. Energie 6:28-30

37. Ministerie van Volkshuisvesting, Ruimtelijke Ordening en Milieubeheer, Nationaal ruimtelijk perspectief windenergie op land (2010). Available via Vereniging Nederlandse Gemeenten, https://www.vng.nl/files/vng/ 20100614_rpw20bij20bo20ruimte202420juni202010_rh.pdf. Accessed 19 February 2015

38. Arentsen M, Bellecom S (2014) Power to the people: local energy initiatives as seedbeds of innovation? Energy, Sustainability and Society $4: 2$

39. Van den Bosch S (2010) Transition experiments, exploring societal changes towards sustainability. Dissertation, Erasmus University Rotterdam

40. Koppenjan J (2012) The new public governance in public service delivery. Eleven international publishing, The Hague

\section{Submit your manuscript to a SpringerOpen ${ }^{\odot}$ journal and benefit from:}

- Convenient online submission

- Rigorous peer review

- Immediate publication on acceptance

- Open access: articles freely available online

- High visibility within the field

- Retaining the copyright to your article

Submit your next manuscript at $>$ springeropen.com 